\title{
Production of non-glycosylated recombinant Pla I 1, the main allergen of Plantago lanceolata
}

\author{
Teresa Stemeseder ${ }^{1 *}$, Stephanie Eichhorn', Sabrina Schuller ${ }^{2}$, Roland Lang ${ }^{3}$, Peter Briza ${ }^{1}$, Thomas Hawranek ${ }^{3}$, \\ Fatima Ferreira', Gabriele Gadermaier ${ }^{2}$ \\ From 5th International Symposium on Molecular Allergology (ISMA 2013) \\ Vienna, Austria. 6-7 December 2013
}

\section{Background}

Pollen of Plantago lanceolata (English plantain) represent a frequent cause of allergic reactions in patients in the temperate regions of Europe, Australia and North America. The major allergen Pla 11 is an Ole e 1-like protein and has been produced as glycosylated protein in yeast. The aim of the study was to express a non-glycosylated Pla 11 and compare to the natural allergen.

\section{Methods}

Recombinant Pla 11.0101 was heterologously expressed in the E. coli strain Rosetta-gami B pLysS and purified using cation exchange and size exclusion chromatography. Natural Pla 11 was obtained by pollen extraction and cation exchange chromatography. Physico-chemical properties of the purified proteins were analyzed in gel electrophoresis, mass spectrometry and circular dichroism. Using sera from Austrian ribwort pollen allergic patients $(n=20)$ the IgE-binding activity of natural and recombinant Pla 11 was investigated in ELISA.

\section{Results}

Recombinant Pla 11 was produced as non-tagged protein with a purity of $>95 \%$ and yielded $24 \mathrm{mg}$ per liter of expression culture. The protein migrated at $15 \mathrm{kDa}$ similar to the non-glycosylated natural counterpart. Mass spectrometry confirmed the primary sequence of rPla 11 and the formation of three disulfide bonds. Natural Pla 11 was purified as a mixture of non-glycosylated and glycosylated protein migrating at 15 and $17 \mathrm{kDa}$ respectively. CD spectrometry revealed an unusual spectrum for the native protein with negative minima at 210 and $204 \mathrm{~nm}$. Thermal denaturation resulted in unfolding of the protein which

'University of Salzburg, Department of Molecular Biology, Division of Allergy and Immunology, Salzburg, Austria

Full list of author information is available at the end of the article was only partially restored upon renaturation. Similar but lower IgE-reactivity of recombinant Pla 11 compared to natural Pla 11 was observed using patients' sera allergic to English plantain.

\section{Conclusion}

The availability of non-glycosylated Pla 11 facilitates molecule-based diagnosis of plantain allergy avoiding unspecific and clinically irrelevant reactivity due to carbohydrate moieties.

\section{Authors' details}

'University of Salzburg, Department of Molecular Biology, Division of Allergy and Immunology, Salzburg, Austria. ${ }^{2}$ University of Salzburg, Christian Doppler Laboratory for Biosimilar Characterization, Salzburg, Austria. ${ }^{3}$ Paracelsus Medical University Salzburg, Department of Dermatology, Salzburg, Austria.

Published: 17 March 2014

doi:10.1186/2045-7022-4-S2-P15

Cite this article as: Stemeseder et al:: Production of non-glycosylated recombinant Pla I 1, the main allergen of Plantago lanceolata. Clinical and Translational Allergy 2014 4(Suppl 2):P15.

Submit your next manuscript to BioMed Central and take full advantage of:

- Convenient online submission

- Thorough peer review

- No space constraints or color figure charges

- Immediate publication on acceptance

- Inclusion in PubMed, CAS, Scopus and Google Scholar

- Research which is freely available for redistribution 